\title{
The Effects of Juvenile Hormone Analogue, Fenoxycarb on the Last Instar Testes of Bombyx mori
}

\author{
Son Instar Bombyx mori Testislerine Juvenil Hormon Analoğu \\ Fenoxycarb'ın Etkileri
}

\author{
Research Article \\ Gamze Turgay İzzetoğlư*, Asiye Pak1, Tuğba Zülfikaroğlu1, Taylan K. Öztürk² \\ 'Ege University, Faculty of Science, Department of Biology, Section of Zoology, izmir, Turkey. \\ ${ }^{2}$ Ege University, Faculty of Science, Department of Biochemistry, İmir, Turkey.
}

\section{A B S T R AC T}

\begin{abstract}
$T^{\text {ne }}$ he development and metamorphosis of insects is regulated by juvenile hormone $(\mathrm{JH})$ and ecdysone hormone, which are worked antagonist. Fenoxycarb is an effective juvenile hormone analogue on many insects. In this study, the effect of fenoxycarb on the last larval stage Bombyx mori testes was investigated. Male Iarvae on the 6th day of the last instar are divided into 2 groups. $1 \mathrm{ng}$ of fenoxycarb dissolved in acetone was topically applied to larvae in the treatment group and the remaining 18 larvae were used as the control group. Control and treated groups were followed to until pupation from day when they showed cocoon spinning behavior. After dissection, several of testes were entreated routine histological processes and photographed. In treatment group, it was seen that fenoxycarb reduced spermatogonium formation by suppressing ecdysone release and caused a decrease in mature sperm. Remaining testes are used to the analysis of total carbohydrate and glycogen content. In conclusion, fenoxycarb has the reducing effect on spermatogenesis and it can cause to decrease of total carbohydrate content because of stress in insects. These histological and biochemical results may be in support of the use of fenoxycarb as an insect growth regulator (IGR) for harmful insects.
\end{abstract}

\section{Key Words}

Fenoxycarb, histology, spectrophotometry, testis of Bombyx.

\section{öz}

öceklerin gelişimi ve başkalaşımı başlıca birbiriyle zıt çalışan juvenil ve ekdizon hormonları tarafından düzenlenir. Fenoxycarb, birçok böcek üzerinde etkili bir juvenil hormon analoğudur. Bu çalışmada, fenoxycarbın son larval evredeki Bombyx mori testisleri üzerindeki etkisi araştırılmıştır. Son instar 6 . güne ait erkek larvalar 2 gruba ayrılmıştır. Bir gruba 1ng fenoxycarb uygulanmış, geriye kalan larvalar kontrol grubu olarak kullanılmıştır. Kontrol ve uygulama grubu larvalar, koza örme davranışı gösterdikleri günden itibaren pupalaşıncaya kadar takip edilmiştir. Diseksiyon sonrası testislerin bir kısmı rutin histolojik işlemlerden geçirilmiş ve fotoğrafları çekilmiştir. Uygulama grubunda fenoxycarbın ekdizon salınımını baskılayarak spermatogonium oluşumunu azalttığı ve olgun spermlerin azalmasına neden olduğu görülmüştür. Diğer kısmı ise toplam karbohidrat ve glikojen içeriğinin analizi için kullanılmıştır. Sonuç olarak, fenoxycarb spermatogenezi azaltıcı bir etkiye sahiptir ve böcekler üzerinde stres oluşturarak toplam karbohidrat içeriğinin de azalmasını etkileyebilir. Bu histolojik ve biyokimyasal sonuçlar fenoxycarbın zararlı böcekler için böcek büyüme regülatörü (IGR) olarak kullanımını destekleyici nitelikte olabilir.

\section{Anahtar Kelimeler}

Fenoxycarb, histoloji, spektrofotometri, Bombyx testisi

Article History: Received: Oct 20, 2017; Revised: Feb 19, 2018; Accepted: Mar 03, 2018; Available Online: Mar $26,2018$.

DOI: $10.15671 /$ HJBC.2018.237

Correspondence to: G. Turgay İzzetoğlu, Section of Zoology, Department of Biology, Faculty of Science, Ege University, İzmir, Turkey. 


\section{INTRODUCTION}

Silkworm Bombyx mori (Lepidoptera, Bombycidae), which is a holometabolous insect; pass through a complete metamorphosis including egg, larval, pupal and adult stages [1]. The male reproductive system of silkworms consists of many structures. These are; a pair of testis, a pair of vas deferens and seminal vesicles, a median ejaculatory duct and various accessory glands [2]. The testis is connected to the seminal vesicle and median ejaculatory duct. It is called the vas deferens channel, which connects the testis to the seminal vesicle. Accessory glands, which are usually present in many species, also open to the vas deferens and ejaculatory duct [3].

In Lepidoptera, testis consists of follicles and many testicular tubules. It is a single median organ that is covered with a common peritoneal membrane $[2,4]$. In each testis follicle a series of stages of development occur. These development stages take place in the growth zone, the maturation zone and the differentiation zone, respectively. When each spermatogonium formed in the germarium is transported to the growth zone, it is introduced into the somatic cell layer forming the cyst. Primary germ cells in the cyst bring about a number of spermatocytes (usually 64 to 256) in mitotic divisions. In the maturation zone, spermatocytes undergo two meiotic divisions, and four haploid spermatids occur from each spermatocyte. In the proximal part of the follicle, the differentiation zone, the spermatids turn into flagellate sperm [2].

Because of the main differences in meiotic division in Lepidoptera, two types of sperm occur. Eupyrene (nucleus) sperms are responsible to fertilize the egg. It has been thought that the apyrene (non-nucleus) sperms have various functions such as helping the seminal vesicles to move the eupyrene sperm from testes, feeding the eupyrene sperm and destroying the sperm from the previous matings [5]. In lepidopterans, apyrene sperm differentiation from eupyrene sperm occurs with exposure to a hemolymphsourced apyrene spermatogenesis-inducing factor [3]. The sperm are transported to the seminal vesicles for storage by peristaltic movements of the vas deferens from the testis [2].
The development and metamorphosis of insects are under the control of several major hormones. Especially prothoracicotropic hormone (PTTH), ecdysone and Juvenile hormone $(\mathrm{JH})$ play an important role in metamorphosis. Neurosecretory cells that found in the invertebrates brain ganglia secrete PTTH. It is also called the brain hormone. Ecdysone regulates normal molting with $\mathrm{JH}$ that is secreted from corpora allata [6]. JH is a multifunctional hormone that plays a role in various physiological events such as molting, metamorphosis, sexual maturation and diapause [7].

The rate of formation of spermatocytes from spermatogonia increases with the level of 20-hydroxyecdysone being high, but high $\mathrm{JH}$ values abolish this increase. The spermatocytes then begin dividing meiosis, which is preserved until the end of the larval period. The peak of the 20-hydroxyecdysone inhibits the meiosis and allows to progress metaphase of the cells. In some insects, JH accelerates spermatogenesis [3].

Among the $\mathrm{JH}$ analogues that prolong larval life in insects, the most active molecule is fenoxycarb which is 0 -ethyl $\mathrm{N}$-[2-(4-fenoxy fenoxy) ethyl] carbamate structure [7]. Fenoxycarb that is a synthetically produced insect growth regulator and it has $\mathrm{JH}$ activity interferes with development in many insects by disrupting the metamorphosis process. When applied at high doses, the larvae may prolong its larval duration, inhibit molting, or cause it to become dauer (permanent) larvae. Fenoxycarb is one of the most commonly used $\mathrm{JH}$ analogues. It is not neurotoxic since it has no anti-cholinesterase activity due to its carbamate structure. It binds to the $\mathrm{JH}$ receptor but cannot be destroyed by the $\mathrm{JH}$ esterase [8].

The prothoracic gland is inactivated between days 0 and 2 of the 5 th larval stage. For this reason, it may secrete ecdysone in response to PTTH from day 3. On the 3rd and 4th days, the ecdysone levels are reduced. The secretory activity starts to increase on the 5th day, and on the 6th day, the first peak occurs of the hormone secretion. Intensive ecdysone release continues on days 7 . and 8 . on the 9th day, this secretion 
makes the second peak. This secretory activity begins to decrease from day 10 [9]. In this study, it was aimed to investigate effects of fenoxycarb on testis and sperm formation in addition total carbohydrate and glycogen content on which day ecdysone activity reach a peak.

\section{MATERIALS and METHODS}

\section{Insect Rearing}

Bombyx mori hybrid eggs used as study material were obtained from Bursa Kozabirlik. After 1012 days, larvae that hatched eggs were fed long day period ( 16 hours light and 8 hours dark). The larvae reared in laboratory conditions at $25 \pm 1^{\circ} \mathrm{C}$ and $75-80 \%$ humidity and they were fed on fresh leaves of mulberry trees that present in Ege University Campus three times a day $[10,11]$.

\section{Application of Fenoxycarb}

On the 6th day of the last instar, larvae were separated from 50 male larvae which selected by looking at the Herold's gland. 1ng of fenoxycarb dissolved in acetone was applied on 15 larvae topically [12]. The remaining 15 larvae were used as the control group. Control and treated groups were followed up to 1, 2, 3, 4 spin, and 0 pupae until pupation from day when they showed cocoon spinning behavior. Three larvae dissected from every group that was followed. 30 larvae were dissected for preparation. Insect physiological water was used during the dissection in order to kept $\mathrm{pH}$ in balance. 20 larvae were dissected for biochemical analyses. Removed testes were kept in $-80^{\circ} \mathrm{C}$ freezer.

\section{Histology}

Testes removed from silkworm larvae were fixed in Bouin's solution for 24 hours. Samples were embedded in paraffin. Tissues were sectioned at a thickness of $5-6 \mu$ by using the microtome. Mayer's Hematoxylin-Eosin (H\&E) was used to stain for tissue section $[13,14]$. The preparates were photographed using ZEN image analysis software with a Zeiss Axio Scope A1 microscope.

\section{Homogenization}

In total 20 larvae were dissected for determination of total carbohydrate content and glycogen. The tissue was weighed and placed in the centrifuge tube with $0.2 \mathrm{ml}$ of sodium sulphate solution ( $2 \%$ aq). $0.8 \mathrm{ml}$ of chloroform and $0.8 \mathrm{ml}$ methanol was stirred in tube and centrifuged at $3000 \mathrm{rpm}$ for $1 \mathrm{~min}$. The supernatant was taken to clean tube. The pellet was used for determination of total glycogen. $0.6 \mathrm{ml}$ of deionized water was added into the supernatant and mixed. Again centrifuged at $3000 \mathrm{rpm}$ for $1 \mathrm{~min}$. The upper fraction was used for determination of total carbohydrate content [15].

\section{Determination of Total Carbohydrate Content}

Van Handel (1985) method was used for that process. $750 \mathrm{mg}$ anthrone was dissolved in 150 $\mathrm{ml}$ deionized water and $380 \mathrm{ml} \mathrm{H}_{2} \mathrm{SO}_{4}$. Before determination, standard solutions were prepared $7.5,15,25,50,100,200$ and $300 \mu l$ glucose solution $(1 \mathrm{mg} / \mathrm{ml})$ in tubes and anthrone reagent was added until the final volume was $5 \mathrm{ml}$. The upper fraction samples were similarly prepared. All of them heated for $17 \mathrm{~min}$ at $90-110^{\circ} \mathrm{C}$. Let cooled and read at $625 \mathrm{~nm}$.

\section{Determination of Total Glycogen}

As determination of total carbohydrate content, standard solutions and pellet samples were also prepared for determination of total glycogen. All of them heated for $17 \mathrm{~min}$ at $90-110^{\circ} \mathrm{C}$. Let cooled and read at $625 \mathrm{~nm}$ [15].

\section{RESULTS}

The control group silkworms showed spinning behavior as expected on the 7 th and 8th day of the 5th larval stage. Fenoxycarb-treated groups also began to spin cocoons with the control group at the same time. No difference was observed in the pupation process. When control and fenoxycarbtreated groups were compared macroscopically, a difference was undetermined.

\section{Histological Results}

When the control group is examined on the 2 nd day of the spin (Figure 1A), the testicular follicles were generally in the appearance of tangerine slices. On the same day, the fenoxycarb-treated group (Figure 1B) showed small deformations in the follicles. 

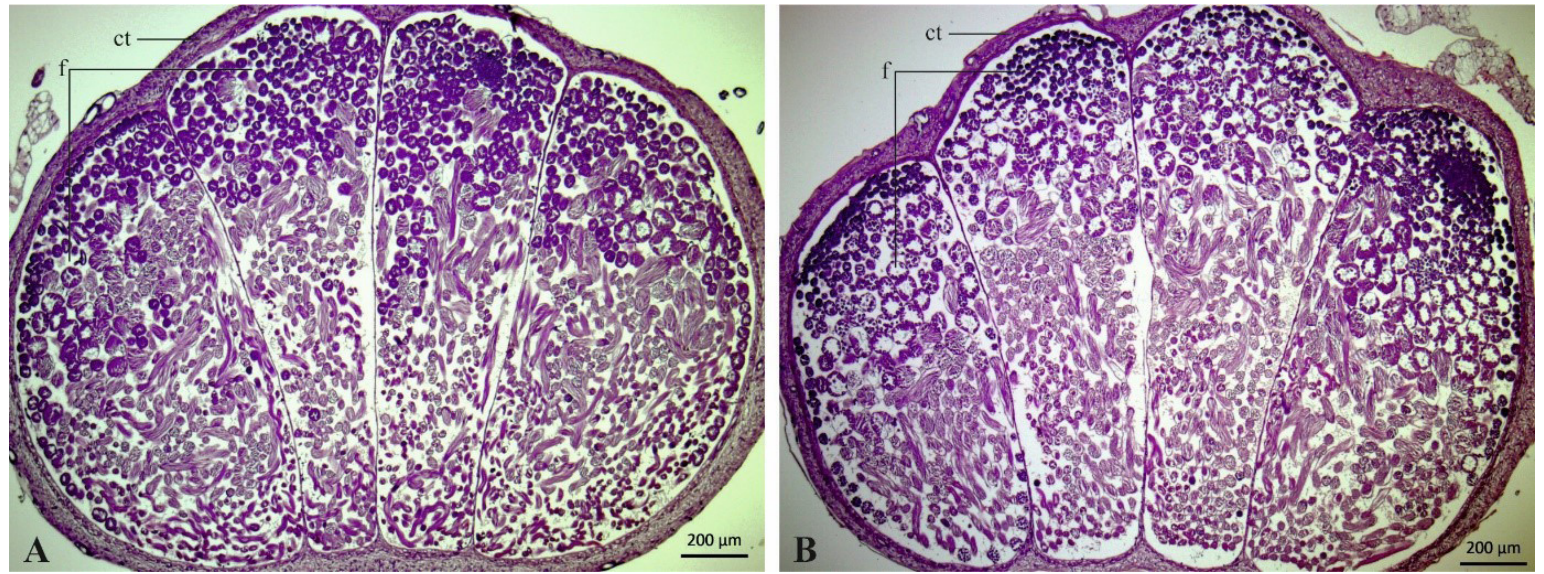

Figure 1. General structure of testis on the 2 nd of spin A. Control group, B. Fenoxycarb-treated group. ct: connective tissue, f: follicle.
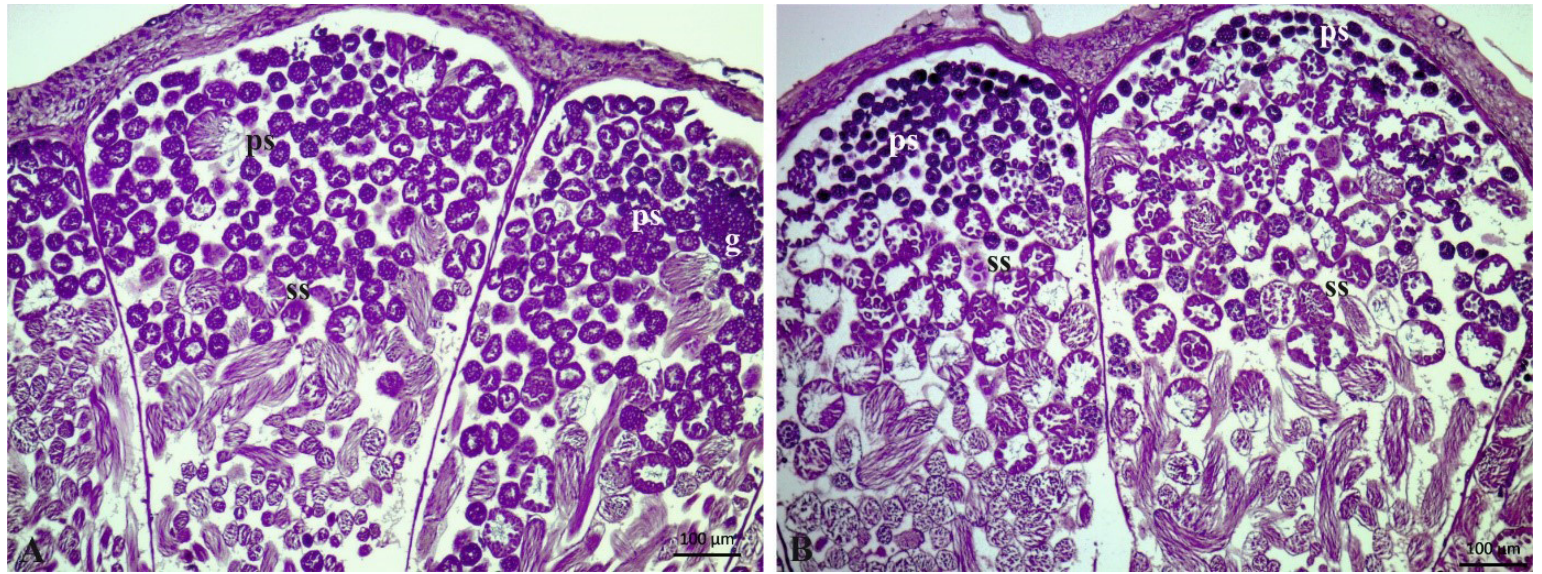

Figure 2. In the growth and maturation region of testis on the 2 nd of spin A. Control group, B. Fenoxycarb-treated group. g: germarium, ps: primary spermatocyte, ss: secondary spermatocyte.

While spermatogonium was found intensively in the growth region of the control group (Figure 2A), it was observed that the amount of spermatogonium decreased in the fenoxycarb group compared to the control group (Figure 2B) on the 2 nd day of the spin.

On the 2nd day of the spin, the spermatids in the maturation region of the control group were observed to be transformed into sperms bunchy in the differentiation zone (Figure 3A). When the fenoxycarb-treated group was examined, it was found that the spermatids were denser but the differentiated sperm were less (Figure 3B). Therefore, it was seen that the eupyrene sperm bundle in the treatment group was less than the control group.
When the control group was examined on the 4th day of spin (Figure 4A), it was observed that there was dense spermatogonium in the growth zone and spermatogonium was less in the fenoxycarb-treated group (Figure 4B).

On the 4th day of spin, the spermatids in the maturation region of the control group (Figure 5A) were observed to be transformed into sperms tightly in the differentiation zone. However, when compared to the application group (Figure 5B), it was found that the conversion of spermatids to sperm was very low and that the sperm was not transformed in tight bundles but in a less rare. It was also found that, on the 4th day, the eupyrene sperm were less in the treatment group than in the control group, as in the second day of spin. 

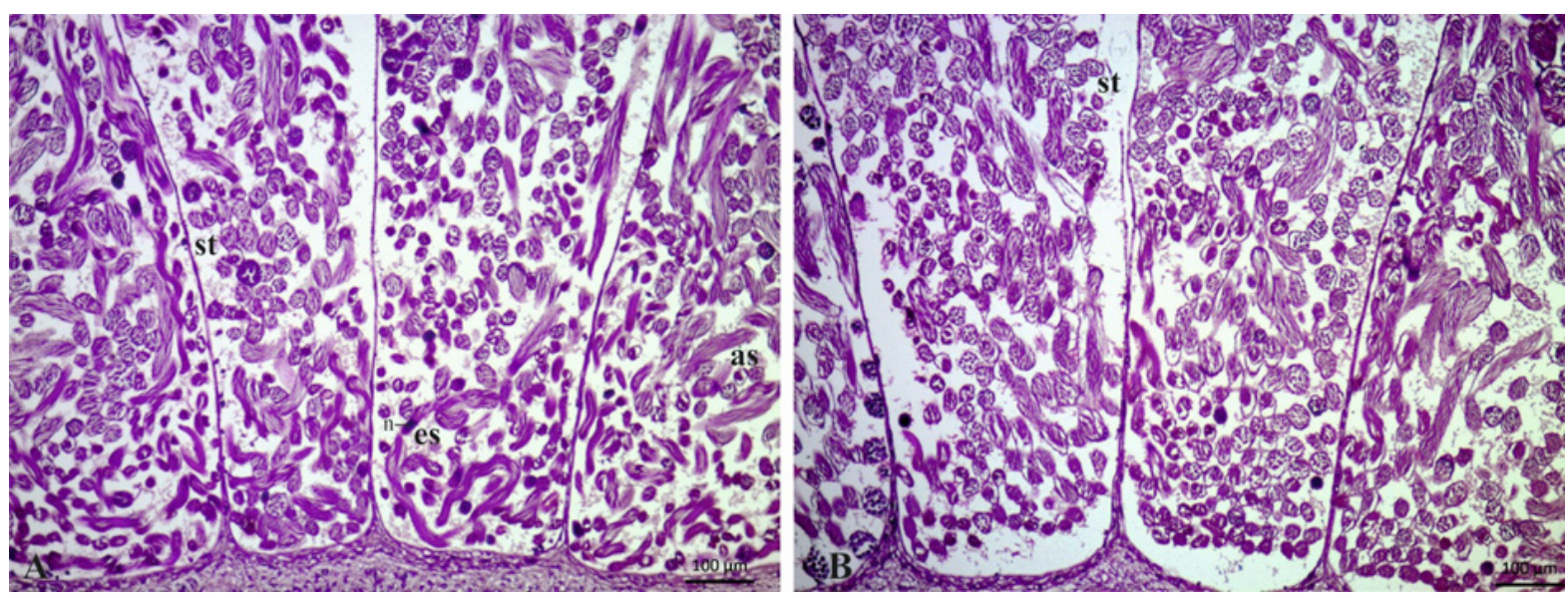

Figure 3. In the maturation and differentiation region of testis on the 2 nd of spin A. Control group, B. Fenoxycarb-treated group. as: apyrene sperm bundle, es: eupyrene sperm bundle, n: nucleus, st: spermatid.
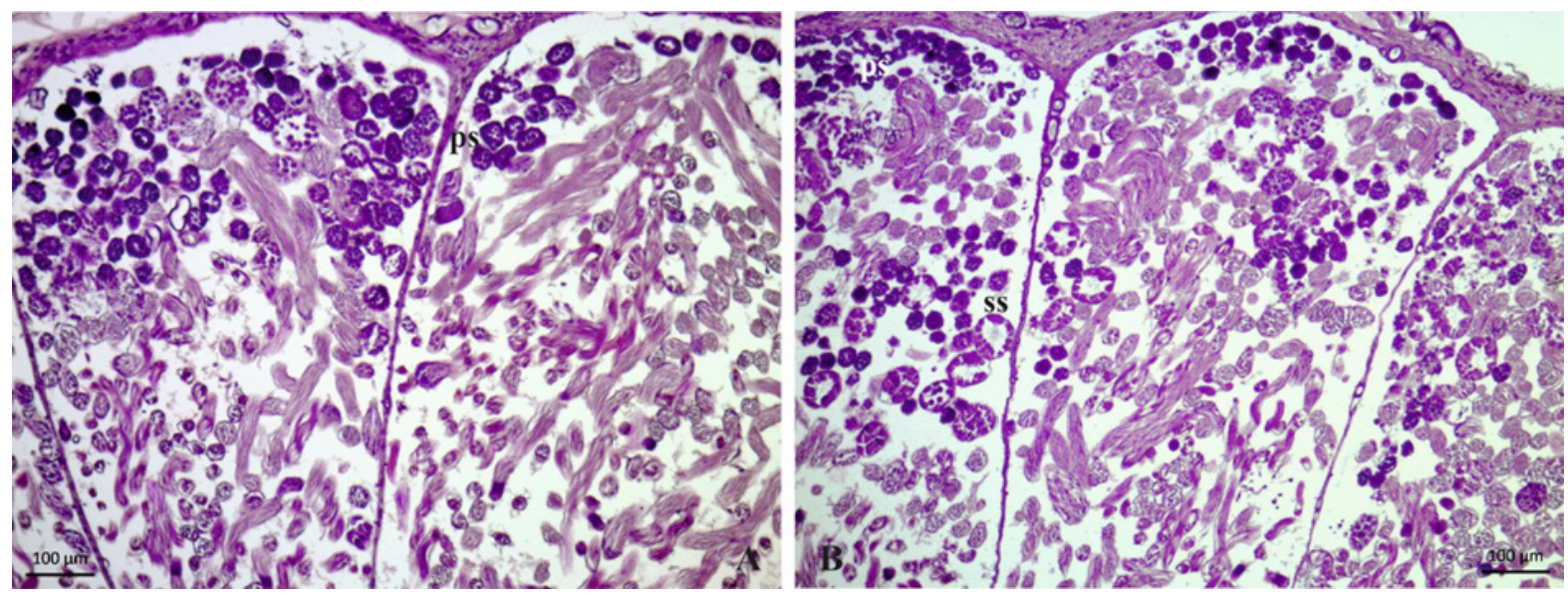

Figure 4. In the growth and maturation region of testis on 4th of spin A. Control group, B. Fenoxycarb-treated group. ps: primary spermatocyte, ss: secondary spermatocyte.

On day 0 (Figures $6 \mathrm{~A}$ and $7 \mathrm{~A}$ ), a decrease in the concentration of spermatogonium was observed in the growth zone of the pupa control group, while an increase in the mature sperm concentration in the differentiation zone was observed. In the group treated with fenoxycarb (Figures 6B and 7B), spermatogonia were found more frequently and mature sperm are less common. Furthermore, there was no significant difference in the eupyrene sperm bundle concentration in the differentiation area were compared in the control and treatment groups.

\section{Total Carbohydrate Content Results}

The total carbohydrate amounts in the two groups were same in the first 24 hours (Table 1). However, 24 hours later fenoxycarb treated group significantly showed remarkable decrease from $0.8 \mathrm{mg}$ to $0.5 \mathrm{mg}$, and control group showed increased carbohydrate from $0.8 \mathrm{mg}$ to $1.3 \mathrm{mg}$. After 48 hours, there was no significant change in carbohydrate content in the treated group, while control group demonstrated slight decrease in carbohydrate content.

\section{Total Glycogen Results}

Glycogen content reached a minimum amount at 96th hour of application for treated and untreated samples as seen Table 2. After this point, slight increase of glycogen content was observed for both group but significant increase was for hormone treated samples. When the rate of formation of glycogen measured after 96 hours was compared, the rate of synthesis in the group of hormones was $0.26 \mathrm{mg} / 24 \mathrm{~h}$, whereas the rate of production in the control group was 0.08 

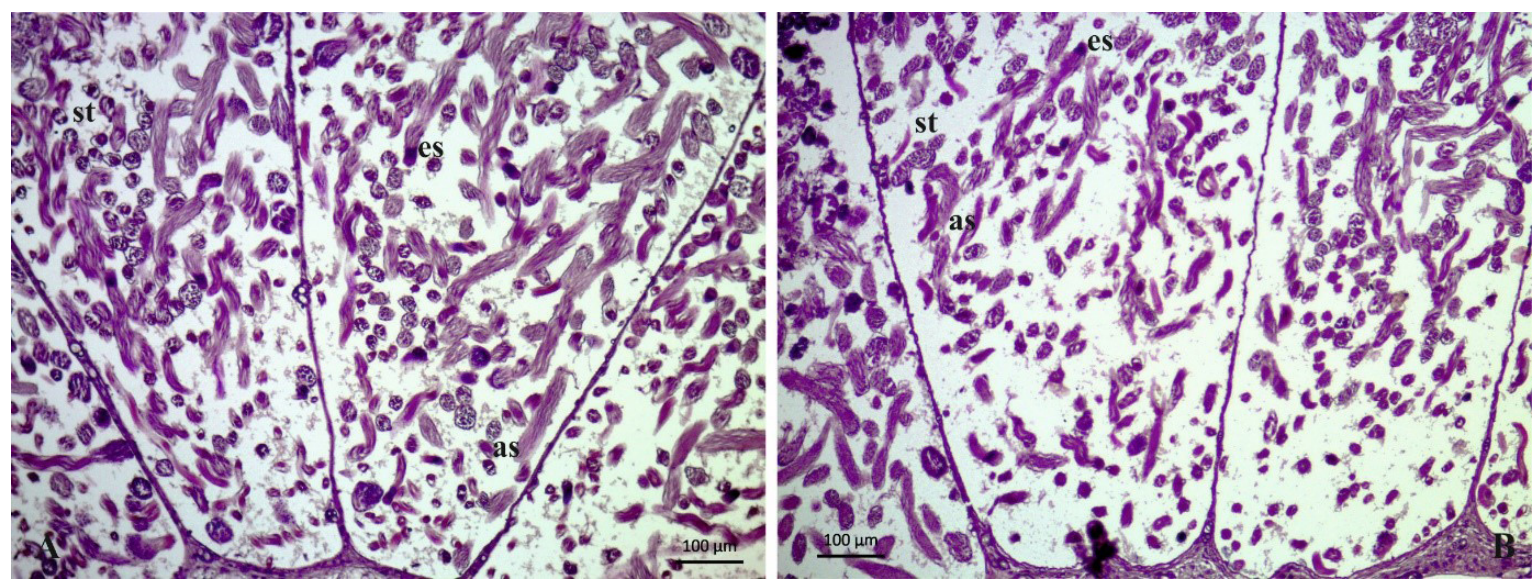

Figure 5. In the maturation and differentiation region of testis on the 4 th of spin A. Control group, B. Fenoxycarb-treated group. as: apyrene sperm bundle, es: eupyrene sperm bundle, st: spermatid.

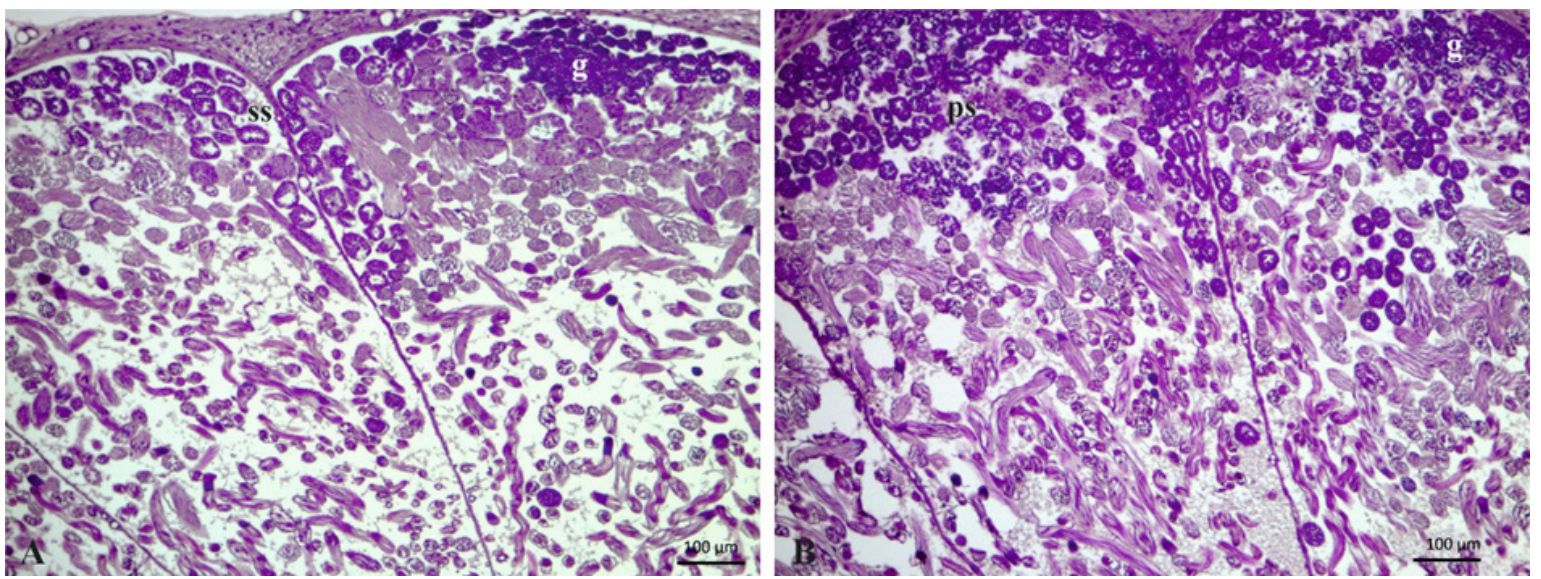

Figure 6. In the growth and maturation region of testis on the Oth of pupa A. Control group, B. Fenoxycarb-treated group. g: germarium, ps: primary spermatocyte, ss: secondary spermatocyte.

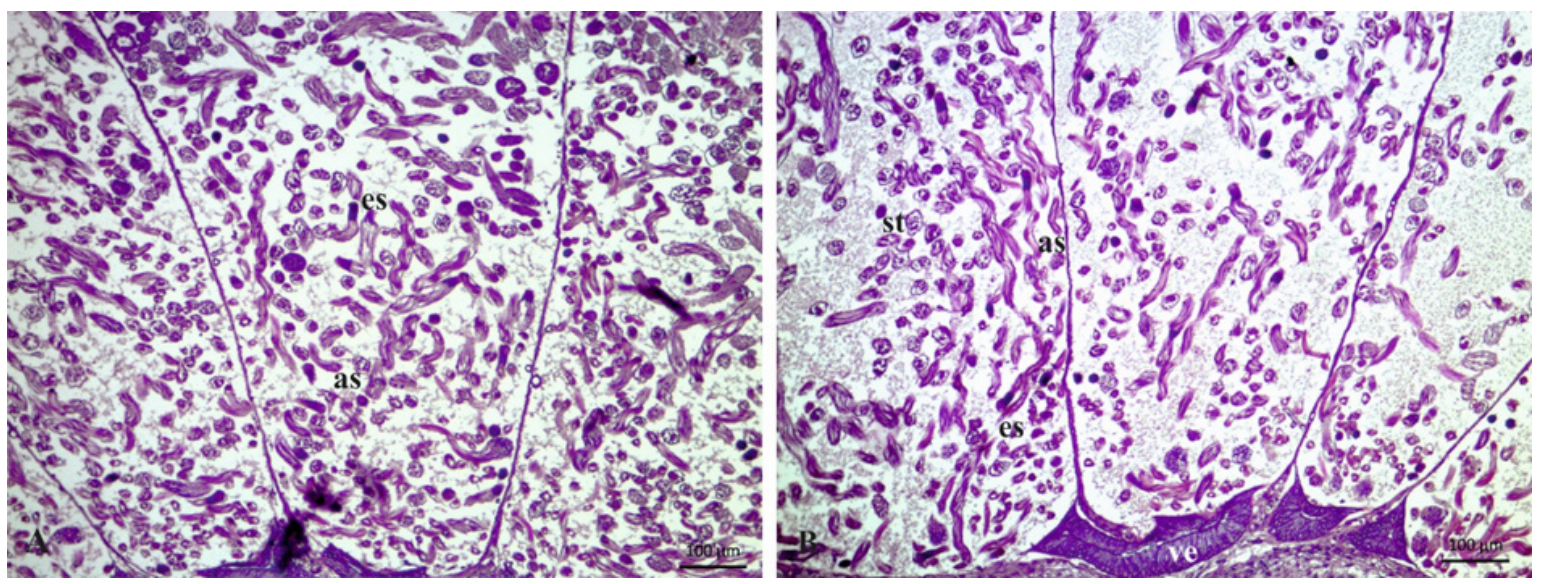

Figure 7. In the maturation and differentiation region of testis on the Oth of pupa A. Control group, B. Fenoxycarb-treated group. as: apyrene sperm bundle, es: eupyrene sperm bundle, st: spermatid, ve: vas efferent. 
Table 1. Total carbohydrate content in Bombyx mori testis between 1st of spin (S) and Oth of pupa (P).

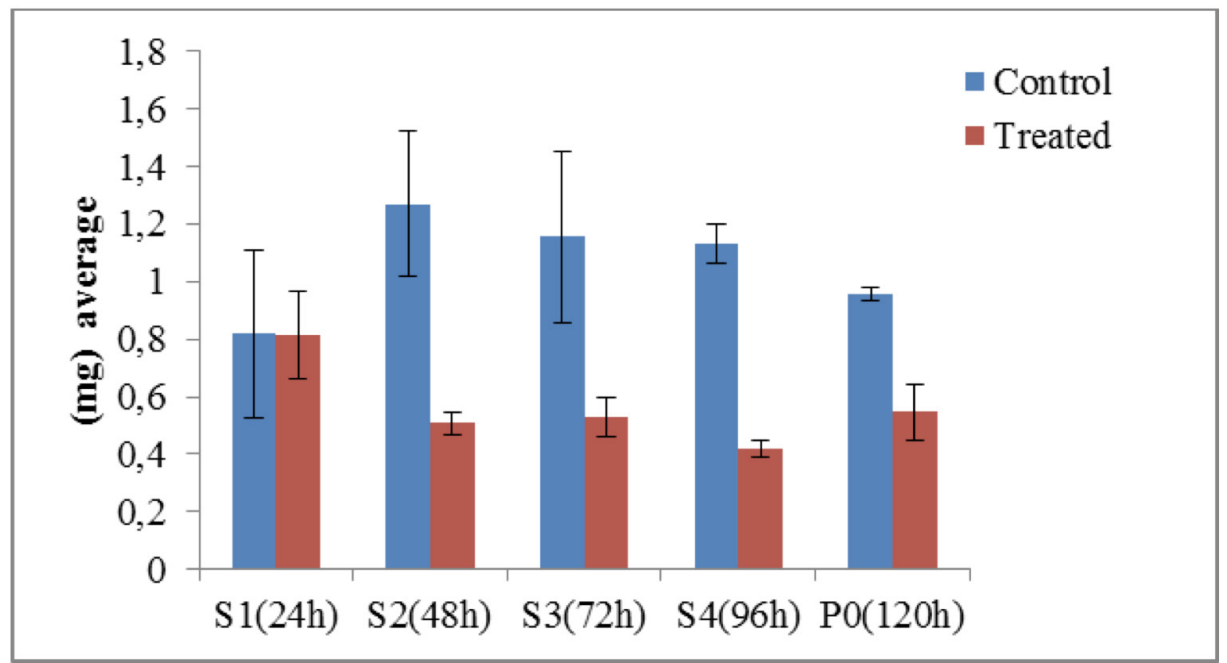

Table 2. Total glycogen content in Bombyx mori testis between 1st of spin (S) and Oth of pupa (P).

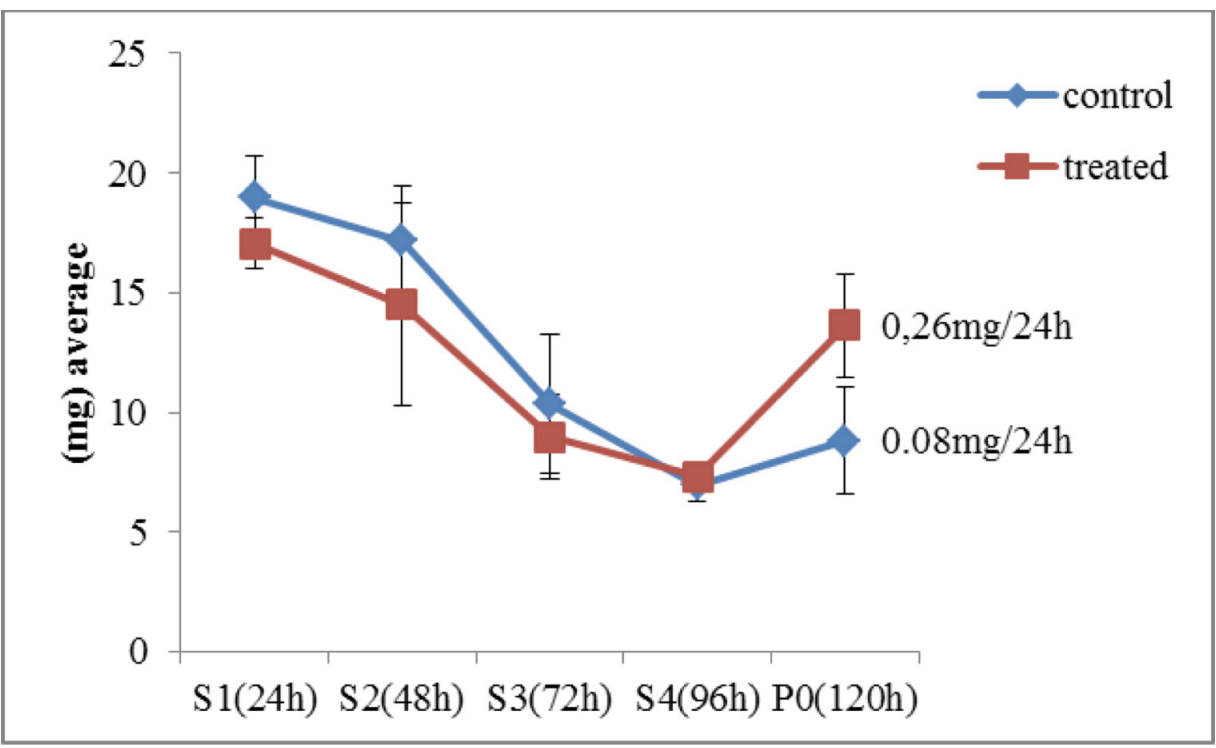

$\mathrm{mg} / 24 \mathrm{~h}$. In fenoxycarb treated group, because the rate of synthesis tripled, demonstrated $50 \%$ increase in glycogen content.

\section{DISCUSSION}

The effect of hormones on the development of insects is quite high. The most important are Juvenile hormone $(\mathrm{JH})$ secreted from corpora allata and ecdysone hormones secreted from the prothoracic gland. JH plays an important role in the development and reproduction of insects. It determines the characteristic of ecdysis in molting and metamorphic processes. Increases in ecdysteroids in the presence of $\mathrm{JH}$ trigger larval-larval ecdyses, but their absence also leads to larval-pupae and then pupal-adult transformations. During larval development, JH or $\mathrm{JH}$ analogous used in many insect, have been reported to damage endocrine balance, resulting cause to be abnormal development [12]. Many experiments were done with fenoxycarb that is an efficient $\mathrm{JH}$ analog and was observed different effects. 
Kamimura and Kiuchi's study [12] has examined the effect of fenoxycarb in the formation of cocoon and pupae during the 5 th larval period. The study was divided into 3 groups in the 5th instar according to the reactions against fenoxycarb. The first group 0-2. on days, fenoxycarb prolonged the eating period and prevented pupation due to dose, but no extra ecdyses was seen. The second group 3-5. on days, fenoxycarb prolonged the eating period and caused an extra ecdyses in the pupal characteristic 6th stage. In both cases, pupation was precisely inhibited. In the third group involving days 6 and 7th, fenoxycarb has only a small effect on subsequent growth.

1ng of fenoxycarb application on day Oth stops the release of ecdysteroids and keeps it below the threshold level required to initiate metamorphic tissue change, thereby extending the eating period It also suppress ecdysteroid release in a complex way. First, fenoxycarb ceases the secretory activity of prothoracic gland to stops the ability of the gland to respond to PTTH. Thus, it prevents PTTH release. After application of fenoxycarb on day 4 , the ecdysteroid titer began to increase and peaked when extra ecdyses started. Contrary to day Oth, treatment on day 4th causes ecdysteroid release because the secretory activity of the prothoracic gland is accelerated [12].

Kamimura [16], Fugo and Dedos [17], Leonardi et al. [18] found that fenoxycarb was effective on larval-pupa ecdyses in silkworms in their studies. Fenoxycarb can also be used for controlling fire ants, fleas, mosquitoes, cockroaches, moths, coccids, and insects attacking vines, olives, cottonseed and fruits [7].

Parlak et al. [19] showed that was delayed the pupal alteration of the larvae, like all other tissues, in the $\mathrm{JH}$ application results on day $\mathrm{O}$ or day 1 of the 5 th instar larvae. $\mathrm{JH}$ is known to be applied as an inhibitory factor for the synthesis of ecdysone secreted by the prothoracic gland in the early 5th instar. Therefore, it is thought that the ecdysteroid levels induce ovarian development and pupal differentiation in the larval stage and $\mathrm{JH}$ inhibit the development of eggs in the larval stage either directly or by suppressing the production of ecdysteroids.
Insects have a balance between synthesis, storage and degradation of nutrients during metamorphosis. According to the study of Pant and Kumar [20], total carbohydrates accumulated during larval stages are used to synthesize of lipid, supply energy need and synthesis of chitin. The rise of total carbohydrate in the larval stages may reflect the use as a potential reserve for pupa-adult development [21]. Another component that accumulates during the larval stage, which has high juvenile hormone value, is glycogen. It is found in entire insect body and used during metamorphosis [22].

Larval forms of holometabolous insects are susceptible to insecticidal stress. Also some pesticides can affect their metabolism of carbohydrates, proteins and lipids [23]. Most researchers determine a reduction of carbohydrate in hemolymph following poisoning with insecticides [24]. The decrease of total carbohydrate content may be indicated production of extra energy to combat insecticidal stress [23].

In this study suggest that as clearly shown in Table 2; the glycogen content of the treatment group is $50 \%$ higher than the control group. In addition, in Table 1, it is seen that the amount of total carbohydrate in control group is increased in order to use in various metabolic activities. However, in the treatment group, fenoxycarb caused a decrease in total carbohydrate content. Therefore, the animal synthesizes more glycogen to preserve homeostasis. As a result, fenoxycarb can cause stress in insects, which causes component content to decrease.

The results in this study suggest that as from the 2nd day of cocoon, fenoxycarb reduced spermatogonium formation by suppressing ecdysone release and caused a decrease in mature sperm. Furthermore, our results show that fenoxycarb also affected sperm productivity by reducing functional eupyrene sperm. In conclusion, fenoxycarb has the effect of reducing the formation of spermatogenesis. These biochemical and histological results may be in support of the use of fenoxycarb as an insect growth regulator (IGR) for harmful insects. 


\section{ACKNOWLEDGEMENT}

We are sincerely grateful to Dr. Ramazan Uranlı for his help with the spectrophotometric analysis.

\section{References}

1. O. Parlak, Ipekböceği Biyolojisi, Ege Üniversitesi Basımevi, İzmir, No: 171 (2001) 127s ISBN 975-483 485-7.

2. C. Gillott, Entomology, 3rd edit., University of Saskatchewan Saskatoon, Saskatchewan, Canada (2005) $831 \mathrm{p}$.

3. M.J. Klowden, In physiological systems in insects, Chapter 4 - Reproductive Systems, 2. edit, University of Idaho, Moscow Idaho (2008) 181-238.

4. N. Kılınçer, Ş. Bayram, Böceklerde üreme sistemleri, Ankara Üniversitesi, Ziraat Fakültesi, Bitki Koruma Bölümü (1999) 59s.

5. J.L. Nation, Insect physiology and biochemistry, 2nd edit., Department of Entomology and Nematology University of Florida, U.S.A (2008) 500 p, ISBN 978 1-4200-6177-2.

6. B. Yılmaz, Omurgasızlarda hormonlar, Ankara Üniv. Vet. Fak. Derg., 35 (1988) 218-226.

7. J. Devillers, Juvenile hormones and juvenoids, 3rd edit., CTIS-centre de traitement de l'information scientifique rillieux la pape, France (2013) 410 p, ISBN 978-1-4665-1322.

8. E. Göncü, O. Parlak, The influence of juvenile hormone analogue, fenoxycarb on the midgut remodeling in Bombyx mori (L., 1758) (Lepidoptera: Bombycidae) during larval-pupal metamorphosis, Turkish J. Ent. 35 (2011) 179-194.

9. E. Batır, E. Göncü, and O. Parlak, Ecdysone receptor B1 in Bombyx mori L. (Lepidoptera:Bombycidae) prothoracic gland under various organ culture conditions, IUFS J. Bio., 71 (2012) 31-42.

10. G. Turgay İzzetoğlu, A. Öber, Histological investigation of the rectal sac in Bombyx mori L., Turk J Zool., 35 (2011) 213-221.

11. G. Turgay İzzetoğlu, A. Öber, Total proteolytic activity on the pupal rectal sac of Bombyx mori L. (Lepidoptera: Bombycidae), Hacettepe J. Bio. Chem. 41 (2013) 67-72.

12. M. Kamimura, M. Kiuchi, Effects of a juvenile hormone analog, fenoxycarb, on 5th stadium larvae of the silkworm, Bomyx mori (Lepidoptera:Bombycidae), Appl. Ent Zool., 33 (1998) 333-338.
13. J.K. Presnell, M.P. Schreibman, Humason's animal tissue techniques, 5th edition, The Johns Hopkins University Press (1997) 572p, ISBN 0-8018-5401-6.

14. A. Öber, Zoolojide Laboratuvar Teknikleri, 3. Baskı, Ege Üniversitesi Basımevi Bornova İzmir, No: 183 (2009) 209s. ISBN 978-975-483-824-4.

15. E. Van Handel, Rapid determination of glycogen and sugars in mosquitoes, J. Am. Mosq. Control Assoc., 1 (1985) 199-301.

16. M. Kamimura, Effects of a juvenile hormone analogue, fenoxycarb, on larval growth of the silkworm, Bombyx mori (Lepidoptera: Bombycidae), JSAEZ, 30 (1995) 487-489.

17. S.G. Dedos, H. Fugo, Induction of dauer larvae by application of fenoxycarb early in the 5 th instar of the silkworm, Bombyx mori, J. Insect Physiol., 45 (1999) 769-775.

18. M.G. Leonardi, S. Cappellozza, L. Cappellozza, P. Lanne, P. Parentis, B. Giordana, Effects of the topical application of an insect growth regulator (fenoxycarb) on some physiological parameters in the fifth instar larvae of the silkworm Bombyx mori, Comp. Biochem. Physiol., 113 (1996) 361-365.

19. O. Parlak, S. Sakurai, M. Kaya, T. Ohtaki, Content and possible role of ecdysterids in the larval ovary of the silkworm, Bombyx mori, Invertebrate Reprod. Develop., 21 (1992) 1-6.

20. R. Pant, S. Kumar, Metabolic fate of carbohydrates and lipids during moulting of Philosamia ricini (Lepidoptera: Saturnidae), Insect Biochem., 9 (1979) 577-582.

21. D. Mandal, D.K. Chaudhuri, Studies on carbohydrate, protein and lipid levels in normal and stress conditions in fat body and integument as compared to whole body during development of rice moth, Corcyra cephalonica (ST), Insect Sci. Applic., 13 (1992) 121-128.

22. M.L.M. Garcia, R.P. Mello, B.C.M. Mello, Effect of Precocene II, Ecdysone and juvenile hormone on the glycogen concentration in pupae of Stomoxys calcitrans (Dipter Muscidae), Mem. Inst. Oswalda Cruz, 83 (1988) 451-454.

23. K. Fotouhi, M.M. Fazel, A. Kavousi, Effects of pyriproxyfen on bioenergetic resources of Leptinotarsa decemlineata (Say) (Coleoptera: Chrysomelidae), Türk. Entomol. Derg., 39 (2015) 11-22.

24. G.J.P. Singh, Hemolymph carbohydrate and lipid mobilization in Locusta migratoria in relation to the progress of poisoning following bioresmethrin treatment, Pest. Biochem. Phys., 25 (1986) 264-269. 